\title{
Meiofauna communities from the Straits of Magellan and the Beagle Channel*
}

\author{
G. T. CHEN ${ }^{1}$, R. L. HERMAN ${ }^{1,2}$ and M. VINCX ${ }^{1}$ \\ ${ }^{1}$ Marine Biology Section, Department of Biology, University of Gent, Ledeganckstraat 35, B-9000 Gent, Belgium. \\ E-mail: guotong.chen@rug.ac.be \\ ${ }^{2}$ present address: Science Policy Administration, Brussels, Belgium
}

\begin{abstract}
SUMMARY: Meiofauna from 20 stations (ranging between 8 and $550 \mathrm{~m}$ ) in the Magellan Straits and the Beagle Channel revealed 28 small sized taxa of higher categories including the temporary meiofauna. Nematoda, Copepoda Harpacticoidea and Polychaeta occurred in all samples; Turbellaria, Bivalvia, Kinorhyncha and Ostracoda were regularly present. Nematodes represented between $68 \%$ and $94 \%$ of the meiofauna at each station, followed by the copepods $(2.3 \%$ to $14.5 \%)$ and polychaetes (1.1\% to 11.5\%). Maximal total density, 9700 individuals $10 \mathrm{~cm}^{-2}$, was found in the surroundings of Picton Island, while the mean abundance per station was 3374 individuals $10 \mathrm{~cm}^{-2}$. The vertical pattern within the sediment showed that $87 \%$ of meiofauna components concentrated in the upper $0-5 \mathrm{~cm}$ sediment layers and $13 \%$ in the lower $(>5 \mathrm{~cm})$ layers. More than $95 \%$ of copepods, as well as the temporary meiofauna occurred in the top $5 \mathrm{~cm}$ layers. The proportion of nematodes and copepods shows opposite trends in the vertical distribution. Multivariate analysis using the total density and the 10 'true' meiofauna taxa densities discriminates between communities in the Straits of Magellan and the Beagle Channel area. Meiofaunal density was much higher in the Beagle Channel, but the diversity was lower than that in the Straits of Magellan. The Southern Magellan meiofauna communities are compared with those found at the Antarctic Peninsula and in the Weddell Sea (high Antarctic). It is considered that hydrodynamic features (tidal currents with strong winds), geographical characteristics, together with sediment composition are the key parameters structuring the meiofauna community in the Straits of Magellan and in the Beagle Channel.
\end{abstract}

Key words: Meiofauna, Density, Community, Straits of Magellan, Beagle Channel, Antarctic.

RESUMEN: Comunidades de Meiofauna del Estrecho de Magallanes y del CANAl DEL BeAgle. - La meiofauna de 20 estaciones (extendiéndose entre 8 y $550 \mathrm{~m}$ ) en el Estrecho de Magallanes y el Canal del Beagle reveló 28 taxones de tamaños pequeños de categorías más altas incluyendo la meiofauna temporal. Nematoda, Copepoda Harpacticoidea y Polychaeta estuvieron presentes en todas las muestras; Turbellaria, Bivalvia, Kinorhyncha y Ostracoda estuvieron regularmente presentes. Los nemátodos representaron entre $68 \%$ y $94 \%$ de la meiofauna en cada estación, seguidos por los copépodos (2,3\% a $14,5 \%$ ) y los poliquetos $(1,1 \%$ a $11,5 \%)$. La densidad total máxima, 9700 individuos $/ 10 \mathrm{~cm}^{2}$, fue encontrada en los alrededores de la Isla de Picton, mientras que la abundancia promedio por estación fue de 3374 individuos $/ 10 \mathrm{~cm}^{2}$, incluyendo la meiofauna temporal. El modelo vertical dentro del sedimento mostró que $87 \%$ de las componentes de la meiofauna se concentraron en las capas superiores del sedimento de $0-5$ centímetros y $13 \%$ en las más bajas ( $>$ capas de los $5 \mathrm{~cm}$ ). Más del $95 \%$ es de los copépodos así como la meiofauna temporal aparecieron en las capas superiores de 5 centímetros. La proporción de nemátodos y de copépods muestra una tendencia opuesta en la distribución vertical. El análisis multivariante usando la densidad total y las 10 densidades 'verdaderas' de los taxones de la meiofauna discrimina las comunidades en el Estrecho de Magallanes y del área del Canal del Beagle. La densidad de la meiofauna fue mucho más alta en el Canal del Beagle, pero la diversidad fue menor que en el Estrecho de Magallanes. Las comunidades meridionales de la meiofauna del Estrecho de Magallanes fueron comparardas con las encontradas en la Península Antártica y en el Mar de Weddell (alta Antártida). Se considera que las características hidrodinámicas (corrientes de marea con vientos fuertes), características geográficas, junto con la composición del sedimento, son los parámetros claves que estructuran la comunidad de la meiofauna en el Estrecho de Magallanes y en el Canal del Beagle.

Palabras clave: Meiofauna, densidad, comunidad, Estrecho de Magallanes, Canal del Beagle, Antártida.

*Accepted November 13, 1998. 


\section{INTRODUCTION}

During 17 October to 25 November 1994 the Chilean-German-Italian R.V. 'Victor Hensen' Campaign was carried out in the Straits of Magellan and the Beagle Channel. The Straits of Magellan is a narrow channel, about $500 \mathrm{~km}$ long which crosses the Sub-Antarctic region of the South American continent, separates Patagonia from Tierra del Fuego and connects the Atlantic and Pacific Oceans (Brambati and Colantoni, 1991). Tides are the most significant hydrodynamic feature in the Straits of Magellan, the highest spring amplitudes in the Atlantic entrance are about $9.0 \mathrm{~m}$; in the central and western basins, tides are of a mixed type, predominantly semidiurnal and mean amplitudes are $1.1 \mathrm{~m}$ (Medeiros and Kjerfve, 1988). The mean annual air temperature is $6^{\circ} \mathrm{C}$ on the Pacific side, $2^{\circ} \mathrm{C}$ in winter season. Surface water salinity ranges from 32.528.0 psu.; for most of the areas the salinity is about 30.8 psu. (Brambati et al., 1991; Panella et al., 1991). The Straits of Magellan is close to the Antarctic and the exchange between the southern tip and the Antarctic is supposed to have been more frequent and longer lasting than between other fragments of Gondwana (Arntz and Gorny, 1996).
Only few reports of quantitative information on the meiofauna communities from the Antarctic have been published so far (Arntz et al., 1994; Bovée, 1977; Bouvy and Soyer, 1989; Herman and Dahms, 1992; Vanhove et al., 1995, 1998). In this paper, the results of a quantitative meiofauna study in the Magellan Region are reported, including higher taxonomic community structures and environmental factors influencing the meiofauna distribution. A comparison is made of the meiofauna communities between the Straits of Magellan, the Beagle Channel, the Antarctic Peninsula and the Weddell Sea.

\section{MATERIAL AND METHODS}

Meiofaunal samples were collected from 20 stations, of which 11 stations were located in the Straits of Magellan and 9 stations in the Beagle Channel, during the R.V. 'Victor Hensen' Joint Magellan Campaign 1994 (Table 1, Fig. 1). The bottom samples were obtained with the multicorer (MUC) which causes little disturbance during sediment sampling. Subsamples for meiofauna studies (up to 5 replicates and each of $10 \mathrm{~cm}^{-2}$ of the surface area) were taken from each station. The sediment samples

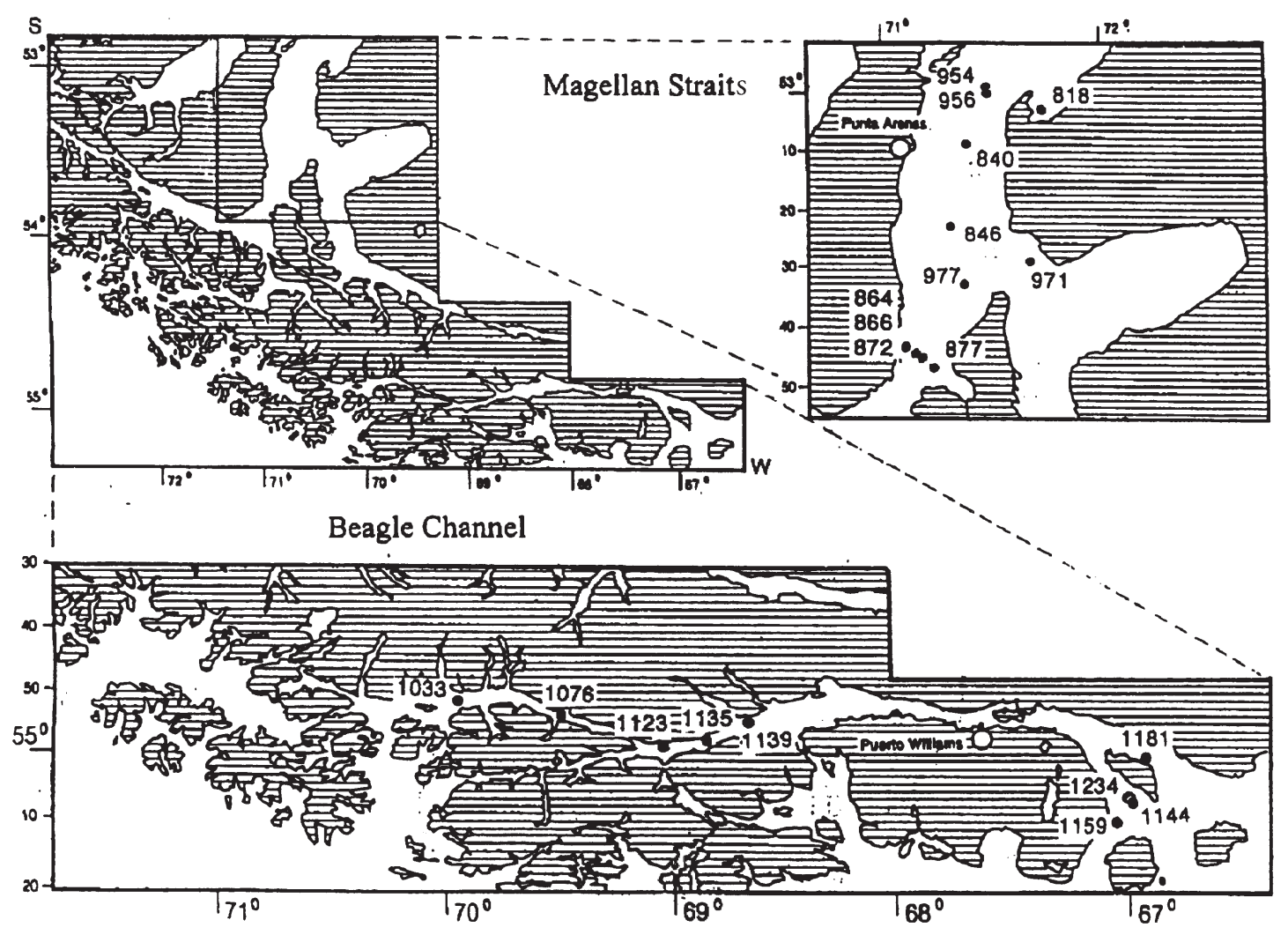

FIG. 1. - Location of the 20 meiofauna sampling stations (solid circles and station numbers) in the Straits of Magellan and the Beagle Channel. 
TABLE 1. - Location of sampling stations and their sedimentological features in the Straits of Magellan and the Beagle Channel.

\begin{tabular}{|c|c|c|c|c|c|c|c|c|}
\hline $\begin{array}{l}\text { Station } \\
\text { No. }\end{array}$ & Date & Lat. S & Long. W & $\begin{array}{l}\text { Depth } \\
(\mathrm{m})\end{array}$ & $\begin{array}{l}\text { Median } \\
(\mu \mathrm{m})\end{array}$ & $\begin{array}{c}\text { Sand \% } \\
(>63 \mu \mathrm{m})\end{array}$ & $\begin{array}{c}\text { Silt \% } \\
(4-63 \mu \mathrm{m})\end{array}$ & $\begin{array}{l}\text { Clay \% } \\
(<4 \mu \mathrm{m})\end{array}$ \\
\hline 818 & 19-Oct-94 & $53^{\circ} 02^{\prime} 6$ & $70^{\circ} 17^{\prime} 2$ & 8 & 33.9 & 8.2 & 80.0 & 11.7 \\
\hline 840 & 23 -Oct-94 & $53^{\circ} 08^{\prime} 8$ & $70^{\circ} 38^{\prime} 4$ & 123 & 28.5 & 22.3 & 59.4 & 18.3 \\
\hline 846 & $23-O c t-94$ & $53^{\circ} 21^{\prime} 6$ & $70^{\circ} 43^{\prime} 3$ & 195 & 65.4 & 51.0 & 39.9 & 9.2 \\
\hline 864 & 25 -Oct-94 & $53^{\circ} 42^{\prime} 6$ & $70^{\circ} 48^{\prime} 7$ & 550 & 17.2 & 20.2 & 57.9 & 22.0 \\
\hline 866 & 25 -Oct-94 & $53^{\circ} 41^{\prime} 8$ & $70^{\circ} 54^{\prime} 6$ & 440 & 13.0 & 11.9 & 65.2 & 23.0 \\
\hline 872 & 25 -Oct- 94 & $53^{\circ} 43^{\prime} 4$ & $70^{\circ} 56^{\prime} 0$ & 351 & 17.3 & 23.9 & 52.6 & 23.6 \\
\hline 877 & 25 -Oct- 94 & $53^{\circ} 41^{\prime} 5$ & $70^{\circ} 56^{\prime} 5$ & 227 & 55.6 & - & - & - \\
\hline 954 & $31-$ - t-94 & $52^{\circ} 59^{\prime} 7$ & $70^{\circ} 33^{\prime} 0$ & 79 & 149.6 & 77.0 & 13.4 & 9.6 \\
\hline 956 & 31-Oct-94 & $52^{\circ} 59^{\prime} 9$ & $70^{\circ} 32^{\prime} 9$ & 80 & 195.2 & 91.6 & 4.4 & 4.0 \\
\hline 971 & 01-Nov-94 & $53^{\circ} 28^{\prime} 9$ & $70^{\circ} 21^{\prime} 9$ & 90 & - & - & - & - \\
\hline 977 & $01-N o v-94$ & $53^{\circ} 33^{\prime} 0$ & $70^{\circ} 39^{\prime} 2$ & 459 & 8.6 & 2.0 & 67.8 & 30.2 \\
\hline 1033 & $04-N o v-94$ & $54^{\circ} 52^{\prime} 7$ & $69^{\circ} 55^{\prime} 2$ & 309 & 8.0 & 1.0 & 72.3 & 26.7 \\
\hline 1076 & 05-Nov-94 & $54^{\circ} 53^{\prime} 6$ & $69^{\circ} 30^{\prime} 3$ & 346 & 15.1 & 7.2 & 75.0 & 17.8 \\
\hline 1123 & 06-Nov-94 & $54^{\circ} 58^{\prime} 7$ & $69^{\circ} 01^{\prime} 9$ & 219 & 11.2 & 8.0 & 67.7 & 24.3 \\
\hline 1135 & 07-Nov-94 & $54^{\circ} 55^{\prime} 0$ & $68^{\circ} 49^{\prime} 9$ & 257 & 7.0 & 0.0 & 67.5 & 32.5 \\
\hline 1139 & $07-N o v-94$ & $54^{\circ} 55^{\circ} 0$ & $68^{\circ} 39^{\prime} 2$ & 255 & 11.0 & 6.6 & 71.8 & 21.6 \\
\hline 1144 & 08 -Nov-94 & $55^{\circ} 08^{\prime} 4$ & $66^{\circ} 54^{\prime} 5$ & 110 & 7.5 & 0.0 & 66.2 & 33.8 \\
\hline 1159 & 10-Nov-94 & $55^{\circ} 08^{\prime} 0$ & $67^{\circ} 01^{\prime} 9$ & 32 & - & - & - & - \\
\hline 1181 & 12-Nov-94 & $55^{\circ} 07^{\prime} 0$ & $66^{\circ} 55^{\prime} 4$ & 110 & 5.3 & 0.0 & 58.9 & 41.1 \\
\hline 1234 & 18-Nov-94 & $55^{\circ} 00^{\prime} 4$ & $66^{\circ} 53^{\prime} 6$ & 100 & 8.9 & 0.0 & 70.2 & 29.8 \\
\hline
\end{tabular}

were divided into two sections, i.e. the top layer (0$5 \mathrm{~cm}$ ) part and the below $5 \mathrm{~cm}$ layer, and were fixed with warm formaldehyde to a final concentration of $4 \%$.

The meiofauna samples were treated in the laboratory by passing through a $1 \mathrm{~mm}$ mesh sieve and retaining on a $38 \mu \mathrm{m}$ sieve. A density-gradient centrifugation technique (Ludox HS $40 \%$ ) was used to extract the meiofauna from the silty sediments (Heip et al., 1985). Meiofauna counting and classification into higher taxa was carried out directly under the stereomicroscope (Leica WILD M8).

Two-way indicator species analysis (TWINSPAN, Hill, 1979) was used to determine the similarity of the station groups. The CANOCO program (Canonical Correspondence Analysis, Ter Braak, 1988) was used for the ordination which reflects the major relations between the meiofauna taxa and/or stations and their environmental parameters. Sediment granulometry was examined by means of a Coulter LS 100 instrument.

Hill's diversity indices (Hill, 1973) were calculated based on the density of meiofauna taxa, as follows:

No $=\mathrm{S}$, (number of meiofauna taxa)

$N_{1}=\exp \left(H^{\prime}\right)$, where $H^{\prime}=-\sum p i \ln p i,\left(H^{\prime}=\right.$ Shannon-Wiener index)

$N_{2}=1 / S I$, Where $S I=\sum p i^{2}$, (Simpson's dominance index)

$N \inf =1 / p_{1}$, $\left(p_{1}\right.$ is the proportion of the most dominant taxon)

Spearman Rank correlation coefficients and regres- sion methods were used to determine the correlation between meiofauna density, diversity and environment variables.

\section{RESULTS}

\section{Sediment granulometric analyses}

The data of sediment granulometric analyses are shown in Table 1. The sediments at the stations in the Beagle Channel (stations 1033-1234) were very homogeneous and characterized by low median grain size (less than $15 \mu \mathrm{m}$ ) and high clay-silt contents (90$100 \%)$. Sediment components in the Straits of Magellan (stations 818-977) were more diverse, the median grain size varied from 8.6 to $195.2 \mu \mathrm{m}$, the percentages of clay-silt ranged from $8.4 \%$ (station 956) to $91.7 \%$ (station 818), the sand content was highest at station $956(91.6 \%)$, and more than $20 \%$ of sand contents were found at the stations 840, 846, 864 and 872 .

\section{Composition of the meiofauna}

Twenty-eight higher taxa (ranging from 9 at station 818 and 22 at station 872) of meiofauna were found in the investigated area and resulted in a mean taxa number of 16 per station (Table 2). Nematodes, copepods (including nauplii) and polychaetes were found at all sites; the relative abundance of these three main taxa represented about $97.0 \%$ in total of the meiofauna community. Bivalves, kinorhynchs, 
TABLE 2. - Average densities of true meiofauna taxa (A) and temporary meiofauna taxa (B) in the Straits of

\begin{tabular}{|c|c|c|c|c|c|c|c|c|c|c|c|c|c|c|}
\hline Copepoda* & 187.5 & 83.5 & 139 & 100.3 & 295 & 303.7 & 223.4 & 134.5 & 91 & 84 & 300.3 & 292.4 & 92 & 140.5 \\
\hline Gastrotricha & - & 2.5 & - & 1 & 0.5 & 0.3 & 0.3 & 6.5 & 3.5 & - & 0.7 & - & 0.3 & - \\
\hline Kinorhyncha & 2 & 4 & 84.7 & 6 & 5.5 & 15 & 41.7 & 20 & 4 & 6 & 17.3 & 20.7 & 10 & 20.5 \\
\hline Loricifera & - & - & - & - & - & - & - & - & - & - & - & - & - & - \\
\hline Nematoda & 1424.5 & 980 & 1664.3 & 2038.3 & 1383.5 & 1880.7 & 3137.7 & 1567.5 & 1029.5 & 1475 & 2497.7 & 4426.7 & 2417.7 & 3547.5 \\
\hline Ostracoda & - & - & 10 & 5 & 10 & 17.7 & 12.3 & 8 & 1.5 & 4 & 20.7 & 17.7 & 2 & 2.5 \\
\hline Turbellaria & 3 & 1 & 7.7 & 38 & 30.5 & 7.7 & 25 & - & 42.5 & 2 & 51.3 & 5.7 & 9.7 & 18.5 \\
\hline Subtotal & 1617 & 1071 & 1905.7 & 2188.6 & 1725 & 2227.1 & 3440.4 & 1741 & 1175.5 & 1588 & 2889.3 & 4766.9 & 2534.8 & 3730 \\
\hline $\begin{array}{l}\text { B. } \\
\text { TaxalStation }\end{array}$ & 818 & 840 & 846 & 864 & 866 & 872 & 877 & 954 & 956 & 971 & 977 & 1139 & 1033 & 1076 \\
\hline Cumacea & - & 2.5 & - & 2 & 3.5 & 1.3 & 0.7 & - & - & 1 & 0.3 & 2 & 2.3 & 2 \\
\hline Echiurida & - & - & 0.3 & - & 0.5 & 0.7 & - & - & - & - & - & - & - & - \\
\hline Gastropoda & - & - & - & - & - & - & 0.3 & - & 3.5 & - & 0.7 & - & - & 1 \\
\hline Echinodermata & 0.5 & 1.5 & - & 0.7 & 0.5 & 0.7 & - & 0.5 & - & - & 0.3 & 0.3 & - & - \\
\hline Hydrozoa & 2 & 0.5 & 4 & 9.7 & 11 & 17 & 1.3 & - & - & 4 & 18.3 & 4.7 & 0.3 & 2 \\
\hline Isopoda & - & - & - & - & - & - & 0.3 & - & - & 1 & - & - & 0.3 & 1.5 \\
\hline Nemertina & - & - & - & - & - & 0.3 & - & - & 0.5 & - & 1.7 & 2 & - & - \\
\hline Oligochaeta & - & 1 & 2 & 5.3 & 2.5 & 17.7 & 9.3 & 5 & 4 & 1 & 9.7 & 3.7 & 2 & 5 \\
\hline Polychaeta & 67 & 58.5 & 89.3 & 140.7 & 235 & 122 & 83.7 & 102 & 83 & 61 & 141.7 & 118.7 & 27.3 & 100 \\
\hline Priapulida & - & 3.5 & - & 0.3 & 1 & 1.3 & 1.7 & - & - & - & 0.7 & - & 1.3 & - \\
\hline Sipunculida & - & 0.5 & - & - & 2.5 & - & 0.3 & - & - & - & - & 4 & - & - \\
\hline Tanaidacea & - & 1 & 3.3 & 1.7 & 3.5 & 3 & 2.3 & 2 & 0.5 & 2 & 1 & 3 & 1.3 & 13 \\
\hline Tunicata & - & - & - & - & - & - & - & - & - & 2 & 2.3 & 2.3 & - & - \\
\hline Subtotal & 71.5 & 101 & 121.2 & 184.4 & 311.5 & 201.6 & 121.9 & 132.5 & 112 & 81 & 208 & 165.4 & 44.1 & 153 \\
\hline
\end{tabular}

* including nauplii

oligochaetes and turbellarians occurred at 19 stations, amphipods, hydrozoans, ostracods and tanaidaceans were found at 17 to 18 stations.

The overall average meiofauna density at all stations was $3374 \pm 571$ ind. $10 \mathrm{~cm}^{-2}$ and ranged from $1172 \pm 335$ ind. $10 \mathrm{~cm}^{-2}$ (station 840 ) to $9682 \pm 1774$ ind. $10 \mathrm{~cm}^{-2}$ (station 1234) (Table 2 and Fig. 2). The maximum density in one replicate was 11624 ind. 10 $\mathrm{cm}^{-2}$. The mean density in the Straits of Magellan (2110 ind. $10 \mathrm{~cm}^{-2}$ ) was obviously lower than that in the Beagle Channel (4920 ind. $10 \mathrm{~cm}^{-2}$ ).

Nematodes were the most abundant taxon and the average density was $2945 \pm 676$ ind. $10 \mathrm{~cm}^{-2}$ which contributed $87.3 \%$ of the meiofauna. The lowest densities of nematodes occurred at station $840\left(980 \pm 291\right.$ ind. $\left.10 \mathrm{~cm}^{-2}\right)$ and station 956 (1030 \pm 129 ind. $\left.10 \mathrm{~cm}^{-2}\right)$. The relative abundance varied from $67.9 \%$ (station 866) to $93.7 \%$ (station 1033). The highest densities of nematodes were found in the surroundings of Picton Island, with the maximum of 8552 ind. $10 \mathrm{~cm}^{-2}$ at station 1234.
Copepods were the second dominant taxon (210 ind. $10 \mathrm{~cm}^{-2}$ ) and represented $6.2 \%$ of relative abundance of meiofauna. The highest density of copepods occurred also at station $1234\left(633\right.$ ind. $10 \mathrm{~cm}^{-}$ ${ }^{2}$ ). Although the average density of copepods in the

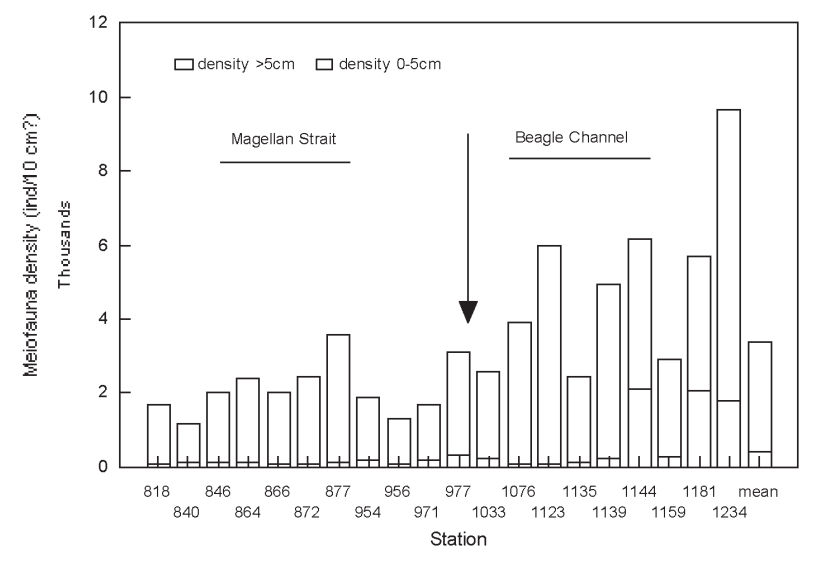

FIG. 2. - Distribution of mean meiofauna densities at 20 stations in the Straits of Magellan and the Beagle Channel. 
Magellan and the Beagle Channel.

\begin{tabular}{|c|c|c|c|c|c|c|c|}
\hline 1123 & 1135 & 1144 & 1159 & 1181 & 1234 & Mean & $\pm \mathrm{SE}$ \\
\hline 288.5 & 56.7 & 313 & 161 & 278.7 & 633.3 & 209.9 & 29.2 \\
\hline 1.5 & - & 0.7 & - & 4 & 3.5 & 1.3 & 0.4 \\
\hline 1 & 1.5 & - & - & - & - & 0.4 & 0.2 \\
\hline 103.5 & 7.7 & 9.3 & - & 15 & 128 & 26.1 & 7.8 \\
\hline- & - & - & - & - & 0.5 & 0.0 & 0.0 \\
\hline 5418 & 2245.7 & 5581.7 & 2536 & 5100 & 8552.3 & 2945.2 & 424.0 \\
\hline 14.5 & 3.5 & 5.7 & 45 & 9.7 & 15.5 & 10.3 & 2.2 \\
\hline 2 & 1.5 & 0.7 & - & - & - & 1.6 & 0.8 \\
\hline- & - & - & - & 0.7 & - & 0.2 & 0.1 \\
\hline 10.5 & 18.7 & 39 & 39 & 47.7 & 34.8 & 21.6 & 3.7 \\
\hline 5839.5 & 2335.3 & 5950.1 & 2781 & 5455.8 & 9367.9 & 3216.6 & 454.3 \\
\hline 1123 & 1135 & 1144 & 1159 & 1181 & 1234 & Mean & $\pm \mathrm{SE}$ \\
\hline 5.5 & 1 & 2.7 & 7 & - & - & 1.9 & 0.4 \\
\hline 2 & 2.5 & - & - & - & - & 1.8 & 0.7 \\
\hline 32 & 3.7 & 8 & - & 4.3 & 9.5 & 17.0 & 2.4 \\
\hline - & - & - & 2 & - & - & 0.1 & 0.1 \\
\hline 1 & - & - & - & - & - & 0.2 & 0.1 \\
\hline 5.5 & - & 0.7 & 2 & 0.7 & - & 1.3 & 0.3 \\
\hline - & - & - & - & - & - & 0.1 & 0.0 \\
\hline - & - & - & - & - & - & 0.3 & 0.2 \\
\hline 0.5 & 0.5 & 0.7 & - & - & - & 0.3 & 0.1 \\
\hline 15 & 3.7 & - & 3 & 0.3 & 0.8 & 4.9 & 1.3 \\
\hline 1.5 & - & - & - & 1 & - & 0.3 & 0.1 \\
\hline - & - & 1.3 & - & - & - & 0.3 & 0.1 \\
\hline 4.5 & 6.3 & 6 & 7 & 5.7 & 6.5 & 5.2 & 0.9 \\
\hline 83.5 & 78 & 188.3 & 115 & 200.3 & 286.5 & 119.1 & 14.0 \\
\hline 3.5 & 1 & 8 & - & 5.3 & 10.5 & 1.9 & 0.6 \\
\hline 3 & 3 & 1 & - & 0.7 & - & 0.8 & 0.3 \\
\hline 5.5 & 0.5 & - & 4 & - & 0.5 & 2.4 & 0.6 \\
\hline- & - & - & - & - & - & 0.3 & 0.2 \\
\hline 163 & 100.2 & 216.7 & 140 & 218.3 & 314.3 & 158.2 & 15.6 \\
\hline 6003 & 2431 & 6167 & 2919 & 5674 & 9682 & 3374.0 & 463.5 \\
\hline
\end{tabular}

Beagle Channel (251 ind. $10 \mathrm{~cm}^{-2}$ ) was higher than in the Straits of Magellan (177 ind. $10 \mathrm{~cm}^{-2}$ ), the relative abundance was higher in the Straits of Magellan $(8.4 \%)$ than in the Beagle Channel $(5.1 \%)$.

Polychaetes were the third important taxon of meiofauna with a mean density of 119 ind. $10 \mathrm{~cm}^{-2}$ and $3.5 \%$ of the relative abundance. The proportion of polychaetes was higher in the Magellan Straits, although there was no big difference in the average density between the Straits of Magellan (108 ind.10 $\mathrm{cm}^{-2}$ ) and the Beagle Channel (133 ind. $10 \mathrm{~cm}^{-2}$ ). Polychaetes were most important at station 866 and represented $11.5 \%$ of the individuals at this station. The highest density of polychaetes occurred at station 1234 (287 ind. $10 \mathrm{~cm}^{-2}$ ).

The mean density of temporary meiofauna bivalves was higher in the Straits of Magellan (21 ind. $10 \mathrm{~cm}^{-2}$ ) than in the Beagle Channel (11 ind. 10 $\mathrm{cm}^{-2}$ ). Kinorhynchs had a mean density of 26 ind. 10 $\mathrm{cm}^{-2}$, and were more abundant in the Beagle Channel $\left(37\right.$ ind. $\left.10 \mathrm{~cm}^{-2}\right)$ than in the Straits of Magellan
(19 ind. $10 \mathrm{~cm}^{-2}$ ). A pronounced high density of kinorhynchs occurred at three stations, i.e., station 846 (85 ind. $10 \mathrm{~cm}^{-2}$ ), station 1123 ( 104 ind. $10 \mathrm{~cm}^{-}$ ${ }^{2}$ ) and station 1234 (128 ind. $\left.10 \mathrm{~cm}^{-2}\right)$. Turbellarians, ostracods, oligochaetes and hydrozoans were commonly distributed in the whole area and the mean densities were $22,10,5$ and 5 ind. $10 \mathrm{~cm}^{-2}$, respectively. The other rare taxa were mainly the larvae of macrobenthos (temporary meiofauna), such as echiurids, gastropods, isopods, nemerteans, priapulids, sipunculids, tunicates and echinoderms, which all occurred in very low individual numbers, and contributed only about $1.0 \%$ of relative abundance of the total.

The total density of meiofauna decreased with increasing water depth in the Beagle Channel ( $\mathrm{p} \leq$ 0.01), whereas a positive correlation was found between total density and water depth in the Straits of Magellan ( $\mathrm{p} \leq \mathrm{0.05}$ ). The abundance of aplacophorans, hydrozoans, cumaceans, echiurids and tanaidaceans were all increased with water depth. Bivalves showed highly positive correlation with the $\%$ of sand $(\mathrm{p} \leq 0.01)$.

It can be concluded that meiofauna taxonomic composition is very different between the Straits of Magellan and the Beagle Channel with the proportion of nematodes being clearly higher in the Beagle Channel, whereas the proportion of copepods, polychaetes and other taxa is higher in the Straits of Magellan.

\section{Vertical distribution of meiofauna}

On the average of all stations, $87 \%$ of the meiofauna components concentrated in the upper $5 \mathrm{~cm}$ sediments. $91 \%$ of the polychaetes occurred in the upper $5 \mathrm{~cm}$ layers. Most meiofauna taxa (copepods and all temporary meiofauna) occurred for more than $95 \%$ of their relative abundance, or even exclusively in the upper layers.

The densities in the lower sediment sections $(>5$ $\mathrm{cm}$ ) ranged from $100-200$ ind $10 \mathrm{~cm}^{-2}$ at most stations. Three stations in the eastern mouth of the Beagle Channel (stations 1144, 1181 and 1234), however, presented very high mean densities of about 2000 ind. $10 \mathrm{~cm}^{-2}$ in the low sediment parts, which represents $34 \%, 37 \%$ and $18 \%$ of the total relative abundance of the meiofauna in these stations, respectively.

It is also interesting to note that the proportion of nematodes in the total abundance of meiofauna is higher in the lower sediment layer (>5 cm, $94.0 \%$ ) 


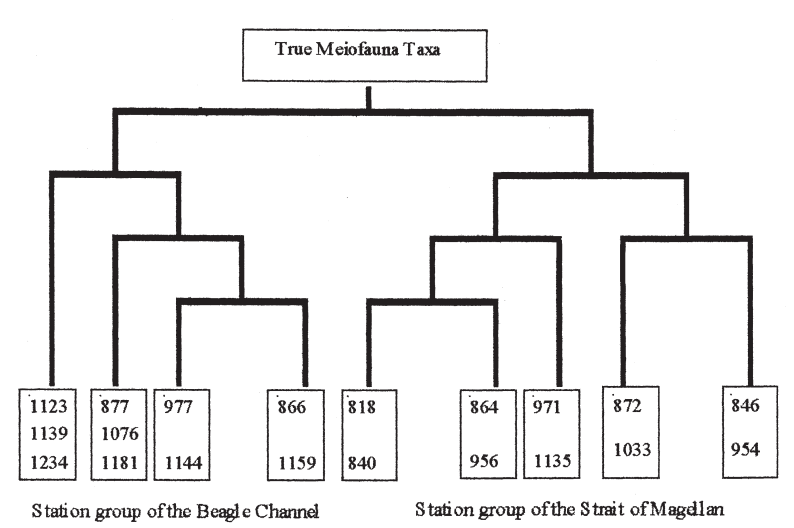

FIG. 3. - Dendrogram of TWINSPAN classification of the meiofauna communities in the Straits of Magellan and the Beagle Channel

than in the upper layer $(0-5 \mathrm{~cm}, 86.3 \%)$, but the proportion of copepods shows the opposite trend $(6.8 \%$ in $0-5 \mathrm{~cm}, 2.5 \%$ in $>5 \mathrm{~cm}$ sediment).

\section{Multivariate analysis of the meiofauna community}

Figure 3 shows the result of the TWINSPAN computed using the densities of 10 permanent meiofauna taxa. The meiofauna samples are divided into two main groups which principally separate the Beagle Channel stations from the Straits of Magellan stations, although a few stations appeared in the other group (stations 866, 877 and 977 occurred in the Beagle Channel group, stations 1135 and 1033 occurred in the Straits of Magellan group). The result of CANOCO (with squareroot transformation of the densities of the 10 meiofauna taxa) shows more or less the same patterns as the TWINSPAN: two groups of sampling stations were distinguished

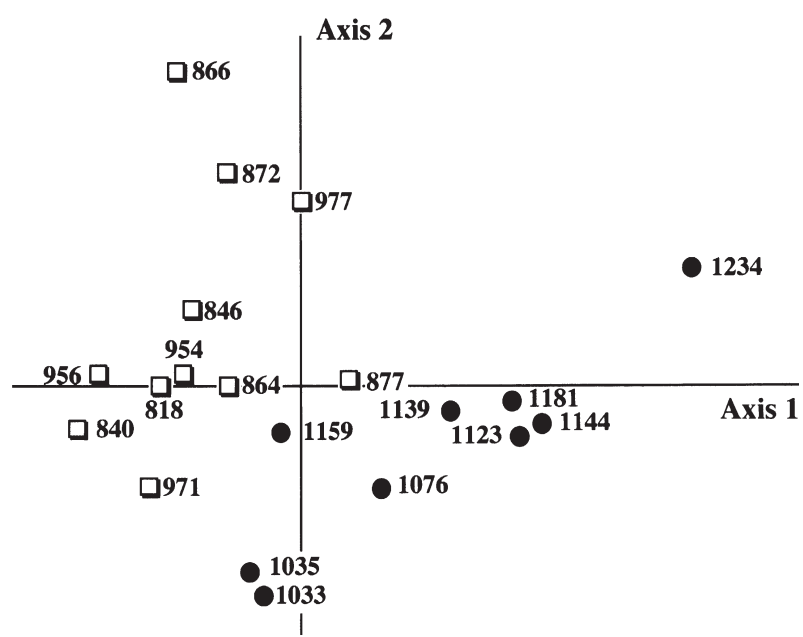

FIG. 4. - Canonical Correspondence Analyses along the two main axes based on the 'true meiofauna' densities for the 20 stations from the Straits of Magellan (o) and the Beagle Channel (I).

(Fig. 4) which are the same as two geographical areas between the Magellan Straits and the Beagle Channel. The first axis (eigenvalue 0.88) is mainly correlated with the amount of silt and the stations of the Beagle Channel distributed along this axis, whereas the second axis (eigenvalue 0.04) is mainly correlated with the water depth and creates the largest distinction in the stations of the Magellan Straits.

\section{Diversity of the meiofauna community}

The diversity indices $\mathrm{No}, \mathrm{N}_{1}, N_{2}, \mathrm{Ninf}$ and $H^{\prime}$ at each of the stations are shown in Table 3. In general, diversities are clearly higher in the Straits of Magellan than at the stations of the Beagle Channel, except for the number of taxa No. Results of the

TABLE 3. - Diversity indices (Hill's numbers $N_{0}, N_{1}, N_{2}$, Ninf and Shannon-Wiener index $H^{\prime}$ ) of the meiofauna community in the Straits of Magellan

\begin{tabular}{|c|c|c|c|c|c|c|c|c|c|c|c|c|c|c|}
\hline $\begin{array}{l}\text { A. } \\
\text { Station }\end{array}$ & 818 & 840 & 846 & 864 & 866 & 872 & 877 & 954 & 956 & 971 & 977 & 1033 & 1076 & 1123 \\
\hline $\begin{array}{l}\text { No } \\
\text { N1 } \\
\text { N2 } \\
\text { Ninf } \\
H^{\prime}\end{array}$ & $\begin{array}{c}9 \\
1.74 \\
1.38 \\
1.19 \\
0.55\end{array}$ & $\begin{array}{c}15 \\
1.99 \\
1.41 \\
1.20 \\
0.69\end{array}$ & $\begin{array}{c}13 \\
2.12 \\
1.46 \\
1.22 \\
0.75\end{array}$ & $\begin{array}{c}17 \\
1.88 \\
1.35 \\
1.16 \\
0.63\end{array}$ & $\begin{array}{c}18 \\
2.96 \\
2.01 \\
1.47 \\
1.08\end{array}$ & $\begin{array}{c}22 \\
2.38 \\
1.62 \\
1.29 \\
0.87\end{array}$ & $\begin{array}{c}18 \\
1.73 \\
1.28 \\
1.14 \\
0.55\end{array}$ & $\begin{array}{c}13 \\
1.99 \\
1.41 \\
1.20 \\
0.69\end{array}$ & $\begin{array}{c}15 \\
2.29 \\
1.54 \\
1.25 \\
0.83\end{array}$ & $\begin{array}{c}15 \\
1.72 \\
1.27 \\
1.13 \\
0.54\end{array}$ & $\begin{array}{c}19 \\
2.21 \\
1.51 \\
1.24 \\
0.79\end{array}$ & $\begin{array}{c}21 \\
1.39 \\
1.14 \\
1.07 \\
0.33\end{array}$ & $\begin{array}{c}16 \\
1.54 \\
1.20 \\
1.09 \\
0.43\end{array}$ & $\begin{array}{c}21 \\
1.62 \\
1.22 \\
1.11 \\
0.48\end{array}$ \\
\hline $\begin{array}{l}\text { B. } \\
\text { Station }\end{array}$ & 818 & 840 & 846 & 864 & 866 & 872 & 877 & 954 & 956 & 971 & 977 & 1033 & 1076 & 1123 \\
\hline $\begin{array}{l}\text { No } \\
\text { N1 } \\
\text { N2 } \\
\text { Ninf } \\
\text { H' }^{\prime}\end{array}$ & $\begin{array}{c}8 \\
2.16 \\
1.76 \\
1.41 \\
0.77\end{array}$ & $\begin{array}{c}14 \\
4.39 \\
3.25 \\
2.30 \\
1.48\end{array}$ & $\begin{array}{c}12 \\
4.81 \\
3.76 \\
2.61 \\
1.57\end{array}$ & $\begin{array}{c}16 \\
4.99 \\
3.52 \\
2.38 \\
1.61\end{array}$ & $\begin{array}{c}17 \\
4.15 \\
2.94 \\
2.21 \\
1.42\end{array}$ & $\begin{array}{c}21 \\
4.39 \\
2.75 \\
1.80 \\
1.48\end{array}$ & $\begin{array}{c}17 \\
4.53 \\
3.01 \\
1.90 \\
1.51\end{array}$ & $\begin{array}{c}12 \\
4.36 \\
3.17 \\
2.28 \\
1.47\end{array}$ & $\begin{array}{c}14 \\
5.12 \\
3.84 \\
2.84 \\
1.63\end{array}$ & $\begin{array}{c}14 \\
4.90 \\
3.36 \\
2.31 \\
1.59\end{array}$ & $\begin{array}{c}18 \\
4.73 \\
3.13 \\
2.00 \\
1.55\end{array}$ & $\begin{array}{c}20 \\
4.75 \\
2.75 \\
1.75 \\
1.56\end{array}$ & $\begin{array}{c}15 \\
5.07 \\
3.58 \\
2.39 \\
1.62\end{array}$ & $\begin{array}{c}20 \\
5.33 \\
3.33 \\
2.03 \\
1.67\end{array}$ \\
\hline
\end{tabular}


TABLE 4. - Comparison of the meiofauna communities between Halley Bay, Kapp Norvegia, Signy Island (all Antarctic) and the present study area.

\begin{tabular}{|c|c|c|c|c|}
\hline Location & $\begin{array}{c}\text { Halley Bay } \\
\text { Herman and Dahms, } 1992\end{array}$ & $\begin{array}{l}\text { Kapp Norvegia } \\
\text { Vanhove, } 1997\end{array}$ & Present study & $\begin{array}{c}\text { Signy Island } \\
\text { Vanhove } \text { et al., } 1998\end{array}$ \\
\hline Water depth (m) & $500-2000$ & $211-2080$ & $8-550$ & $7-9$ \\
\hline Total taxa number & 28 & 24 & 28 & 11 \\
\hline Taxa per station & 10.8 & 11 & 16 & \\
\hline Density range (ind./10 $\mathrm{cm}^{2}$ ) & $792-3119$ & $811-5122$ & $1172-9682$ & $4900-13200$ \\
\hline Mean density (ind. $/ 10 \mathrm{~cm}^{2}$ ) & 1677 & & 3374 & 9000 \\
\hline Nematoda (ind. $/ 10 \mathrm{~cm}^{2}$ ) & $1578(94.1 \%)$ & $1857(82.5-96.4 \%)$ & $2945(87.3 \%)$ & $7500(83.3 \%)$ \\
\hline Harpacticoidea (ind. $/ 10 \mathrm{~cm}^{2}$ ) & $50(3.0 \%)$ & 71 & $175(5.0 \%)$ & $1300(14.4 \%)$ \\
\hline Kinorhyncha (ind./10 $\mathrm{cm}^{2}$ ) & $20(1.2 \%)$ & 17 & $26(0.8 \%)$ & \\
\hline Polychaeta (ind. $/ 10 \mathrm{~cm}^{2}$ ) & $11(0.7 \%)$ & 17 & $119(3.5 \%)$ & \\
\hline V.D. $*(0-5 \mathrm{~cm})$ & $97.4 \%$ & & $87.4 \%$ & \\
\hline V.D. $(>5 \mathrm{~cm})$ & $2.6 \%$ & & $12.6 \%$ & \\
\hline
\end{tabular}

* Vertical distribution

diversity calculated without nematodes show that station 818 has clearly the lowest value of all the diversity indices. Five stations in the eastern mouth of the Beagle Channel (including station 1139) are lower in diversity indices $N_{1}, N_{2}$ and $H^{\prime}$. Thus, the higher dominance of nematodes in the Beagle Channel results in an overall lower diversity here as compared with the Magellan Straits. The number of taxa is strongly correlated with depth (Spearman rank $\mathrm{p}<0.001$ ), and the diversity indices, except for $N_{0}$, are negatively correlated with the silt content $(\mathrm{p}<0.05) . N_{1}$ and $H^{\prime}$ are positively correlated with $\%$ of sand $(\mathrm{p}<0.05)$.

\section{DISCUSSION}

\section{Comparison with the Antarctic area}

The number of higher meiofauna taxa in this study is very similar to Kapp Norvegia and the Halley Bay area in the Weddell Sea (Herman and

and the Beagle Channel. A. including nematodes; B. without nematodes

\begin{tabular}{|c|c|c|c|c|c|c|c|}
\hline 1135 & 1139 & 1144 & 1159 & 1181 & 1234 & Mean & $\pm \mathrm{SE}$ \\
\hline $\begin{array}{c}17 \\
1.50 \\
1.17 \\
1.08 \\
0.41\end{array}$ & $\begin{array}{c}18 \\
1.61 \\
1.23 \\
1.11 \\
0.47\end{array}$ & $\begin{array}{c}16 \\
1.54 \\
1.22 \\
1.10 \\
0.43\end{array}$ & $\begin{array}{c}11 \\
1.80 \\
1.32 \\
1.15 \\
0.59\end{array}$ & $\begin{array}{c}15 \\
1.58 \\
1.23 \\
1.11 \\
0.46\end{array}$ & $\begin{array}{c}13 \\
1.65 \\
1.27 \\
1.13 \\
0.50\end{array}$ & $\begin{array}{l}16.10 \\
1.86 \\
1.36 \\
1.17 \\
0.60\end{array}$ & $\begin{array}{l}0.73 \\
0.08 \\
0.04 \\
0.02 \\
0.04\end{array}$ \\
\hline 1135 & 1139 & 1144 & 1159 & 1181 & 1234 & Mean & $\pm \mathrm{SE}$ \\
\hline $\begin{array}{c}16 \\
5.53 \\
3.67 \\
2.43 \\
1.71\end{array}$ & $\begin{array}{c}17 \\
4.03 \\
2.53 \\
1.73 \\
1.39\end{array}$ & $\begin{array}{c}15 \\
3.44 \\
2.53 \\
1.87 \\
1.24\end{array}$ & $\begin{array}{c}10 \\
4.45 \\
3.46 \\
2.39 \\
1.49\end{array}$ & $\begin{array}{c}14 \\
3.63 \\
2.73 \\
2.06 \\
1.29\end{array}$ & $\begin{array}{c}12 \\
3.41 \\
2.55 \\
1.78 \\
1.23\end{array}$ & $\begin{array}{l}15.1 \\
4.41 \\
3.08 \\
2.12 \\
1.46\end{array}$ & $\begin{array}{l}0.73 \\
0.17 \\
0.11 \\
0.08 \\
0.05\end{array}$ \\
\hline
\end{tabular}

Dahms, 1992; Vanhove et al., 1995; Vanhove, 1997). Nematodes, copepods, polychaetes and kinorhynchs are the dominant taxa in both study areas. However, the overall mean density and number of taxa per station is higher in the Straits of Magellan and the Beagle Channel (Table 4). Furthermore, Polychaetes were found more abundant in the Straits of Magellan and the Beagle Channel than in the Weddell Sea.

Compared with the coastal waters of the Antarctic Peninsula (Signy Island, water depth 7-9 m, Vanhove et al., 1998), with densities in the range of 4900-13200 ind. $10 \mathrm{~cm}^{-2}$ and a mean of 9000 ind. 10 $\mathrm{cm}^{-2}$, densities are much lower in the Beagle Channel and the Magellan Straits.

Kinorhynchs seem to be more dominant in very silty sediments both in Halley Bay and in the Beagle Channel (stations 1123 and 1234), although they also occurred in quite large numbers at the sandy station 846.

In the Halley Bay area, about $97 \%$ of the total meiofauna is restricted to the upper $5 \mathrm{~cm}$ sediment layer; this indicates that in the Weddell Sea only $3 \%$ of meiofauna lives in the lower sediment layers. In the Straits of Magellan and the Beagle Channel, however, the relative abundance of meiofauna in the lower sediment layer varies between 2-10\% at the most of the stations, whereas in the eastern mouth of the Beagle Channel, a pronounced proportion of the meiofauna (30\%) inhabits the deeper layers. These clay-silt stations at a depth of $100 \mathrm{~m}$ also contained a high number of taxa (8-9 taxa per station) in the deeper layers.

\section{Meiofauna community and its environment}

Bouvy and Soyer (1989) studied the meiofauna abundance in an intertidal mudflat at Kerguelen 
Islands, and found the mean nematode percentages lower in the oxidized layer than under the redox potential discontinuity (RPD) layer; for copepods, however, higher abundances were found in the oxidized layer and lower ones under the RPD layer. This phenomenon indicates that copepods are more sensitive to decreased oxygen, but nematodes have the capability of tolerating hypoxic or even anoxic conditions (Coull, 1988; Ott and Schiemer, 1973). Although the RPD layer is not determined in this study, this tendency is observed also in the Straits of Magellan and the Beagle Channel, where the relative abundance of nematodes and copepods between the upper $0-5 \mathrm{~cm}$ and deeper than $5 \mathrm{~cm}$ sediment layers showed the opposite trend.

As stated by Dinet (1979), Thiel (1979), Snider et al. (1984), Shirayama (1984), Pfannkuche (1985), Soetaert et al. (1991), Vincx et al.(1994) and many others, meiofauna abundance and density decreases with increasing water depth. This negative relationship between water depth and the abundance of meiofauna is caused mainly by surface productivity and the distance from land (Bovée et al., 1990). This phenomenon, however, does not exist in the Straits of Magellan. In fact, lowest meiofauna densities were found in localities with a water depth shallower than $100 \mathrm{~m}$. The Magellan Straits is a channel ecosystem, where the distance from land is always short as compared to the open ocean.

Erosion, transport and redeposition of sediments are major sources of physical disturbance for softsediment habitats and associated benthic communities, during periods with very strong currents, resulting in greatly reduced abundance of all size categories of organisms (Aller, 1989; Thistle et al., 1985). Tides and currents are the main hydrodynamic features in channel environments. Tidal current velocities were recorded up to $4.5 \mathrm{~m} \mathrm{~s}^{-1}$ at the narrow passages of Primera and $3.0 \mathrm{~m} \mathrm{~s}^{-1}$ at Segunda Angostura (Medeiros and Kjerfve, 1988). Michelato et al. (1991) reported a maximum speed of $20 \mathrm{~cm} \mathrm{~s}^{-1}$ for the near-bottom (189 m) current in the centre of Paso Ancho. On the other hand, currents are also generated or strengthened by the predominantly westerly winds, strong winds up to 27 $\mathrm{m} \mathrm{s}^{-1}$ are common during winter and spring, in correspondence with the influx of air masses of Antarctic (Medeiros and Kjerfve, 1988; Panella et al., 1991; Brambati and Colantoni, 1991). A wind speed of about $50 \mathrm{~km} \mathrm{~h}^{-1}=14 \mathrm{~m} \mathrm{~s}^{-1}$ will result in a mixed layer of $67 \mathrm{~m}$ depth and a surface current of $20 \mathrm{~cm} \mathrm{~s}^{-1}$ (Figueroa and Yuras, 1996). Palmer and
Gust (1985) reported that transport of meiobenthos was primarily a passive process resulting from mechanical removal due to current scour. This physical process is typically dominant in the upper few centimetres $(0-5 \mathrm{~cm}$ or even up to $10 \mathrm{~cm})$ of the sediment, where most of the meiofauna is living. There is no doubt that meiofauna in the water column comes from sediments during resuspension, and that meiofauna is highly under predation pressure. Gutt and Schickan (1996) found the richest epibenthic species associations in terms of abundance and biomass in the shallow areas (approx. 15 - $130 \mathrm{~m}$ ) in the Straits of Magellan. It is interesting to note that the lowest meiofauna densities were found in the same depth range, which may suggest that the lower abundance of meiofauna at the shallow water stations $(<100 \mathrm{~m})$ is most likely the result of removal by the strong tidal currents and high predation pressure in the Straits of Magellan.

Diaz et al. (1994) stated that activities of benthic organisms combined with physical processes can alter primary structures of fine-grained sediments. In the sediment accumulation area, infaunal communities are well developed with high abundance and biomass, and the surface sediments are completely dominated by biogenic structures created by the activities of a deep burrowing infauna. The meiofauna density in the Beagle Channel is much higher than that in the Straits of Magellan. The stations with the highest meiofauna densities (stations 1144, 1184 and 1234) have clay-silt sediment textures, which indicates this area to be a low energetic and sedimentation environment where a huge amount of fine particles with organic matter and detritus is settled down (Brambati et al., 1991). These rich food sources may support an abundant meiofauna community as has also been reported for the Arctic and the Antarctic (Pfannkuche and Thiel, 1987; Vanhove et al., 1995). Bovée et al. (1990) reported temporal variability of meiofauna abundance in relation to seasonal fluxes of organic matter into the benthos. The meiofauna density tends to increase in finer sediment with more "available resources" as e.g. deposited organic matter which represents the major food source for the mainly deposit-feeding meiofauna (Thiel, 1983; Vanreusel et al., 1992). It is, therefore, supposed that the abundant meiofauna populations occurring in the lower sediment layers of the Beagle Channel, are related to sedimentation and sediment structure. We also found quite a high density of Copepoda harpacticoidea (>90 ind. $10 \mathrm{~cm}^{-2}$ ) in the deeper layers at these localities. 
A decrease of diversity with increasing environmental fluctuations has been observed by Ott and Machan (1971). Station 818 is $8 \mathrm{~m}$ depth and has the lowest diversities which might thus be affected by strong tidal currents in the Straits of Magellan. Warwick et al. (1991) stated that the most important environmental variables controlling or affecting the distribution and abundance of benthic animals in estuaries are salinity and several interrelated sediment variables (grain size, organic content), which in turn are determined by the hydrodynamic features of the estuary. The Straits of Magellan is a special area which is influenced strongly by the tidal currents. The hydrodynamics do not only affect meiofauna through their effects on environmental variables, but also influence the stability of the sediment and the nature of the food supply. The eastern mouth of the Beagle Channel has high sedimentation which results in food enrichment, thus creating a unique environment for the meiofauna community. Both the TWINSPAN (Fig. 3) and the ordination (Fig. 4) illustrate that grouping of the stations largely covers their geographical distribution in the Straits of Magellan and in the Beagle Channel. The hydrodynamic features (tidal current and frequent western winds), together with the sediment composition, are the most important environmental factors influencing meiofauna distribution in this highly dynamic system.

\section{ACKNOWLEDGEMENTS}

The first author is sincerely grateful to Prof. Dr. A. Commans and the Marine Biology Section, Biology Department of Gent University for the facilities available and grant support during the study. Thanks to Mr. G. de Smet, and M. Bruyneel for the sediment granulometric analyses and technical help. We are also grateful to Prof. Wolf Arntz for his review of the manuscript.

\section{REFERENCES}

Aller, J.Y. - 1989. Quantifying sediment disturbance by bottom currents and its effect on benthic communities in a deep-sea western boundary zone. Deep-Sea Res., 36: 901-934.

Arntz, W. and M. Gorny. - 1996. Cruise report of the Joint ChileanGerman-Italian Magellan "Victor Hensen" Campaign in 1994. Ber Polarforsch., 190: 1-113.

Arntz, W., T. Brey and V.A.Gallardo. - 1994. Antarctic zoobenthos. Oceanogr. Mar. Biol. Ann. Rev., 32: 241-304.

Bouvy, M. and J. Soyer. - 1989. Benthic seasonality in an intertidal mud flat at Kerguelen Islands (Austral Ocean). The relation- ships between meiofaunal abundance and their potential microbial food. Polar Biol., 10: 19-27.

Bovée, F. de, L.D. Guidi and J. Soyer. - 1990. Quantitative distribution of deep-sea meiofauna in the northwestern Mediterranean (Gulf of Lions). Cont. Shelf Res., 10: 1123-1145.

Bovée, F. de. - 1977. Le méiobenthos des Iles Kerguelen. Données quantitatives. III. Conclusions. In: Le Benthos du plateau continental des Iles Kerguelen. Résultats scientifiques de la campagne MD 04/benthos du "Marion Dufresne" et des prospections de 1972 à 1975 de "La Japonaise". C. N.F.R. A., 42: 259-265.

Brambati, A. and P. Colantoni. - 1991. Preliminary report on a seismic survey in the Strait of Magellan. Boll. Oceanol. Teor. Appl.., 9 (2-3): 99-106.

Brambati, A., G. Fontolan and U. Simeoni. - 1991. Recent sediments and sedimentological processes in the Strait of Magellan. Boll. Oceanol. Teor. Appl.., 9 (2-3): 217-260.

Coull, B.C. - 1988. Ecology of the marine meiofauna. In: R. P. Higgings and $\mathrm{H}$. Thiel (ed.), Introduction to the Study of Meiofauna, pp. 18-38. Smithsonian Institution Press, Washington D.C.

Diaz, D.J., G.R. Cutter and D.C. Rhoads. - 1994. The importance of bioturbation to continental slope sediment structure and benthic processes off Cape Hatteras, North Carolina. Deep-Sea Res., 41(4-6): 719-734.

Dinet, A. - 1979. A quantitative survey of meiobenthos in the deep Norwegian Sea. Ambio Spec. Rep., 6: 75-77.

Figueroa, D. and G. Yuras. - 1996. Physical oceanography of the Strait of Magellan. In: W. Arntz and M. Gorny (eds), Cruise Report of the Joint Chilean-German-Italian Magellan ,Victor Hensen " Campaign in 1994. Ber. Polarforsch., 190: 20-22.

Gutt, J. and T. Schickan. - 1996. Epibenthic communities analyzed by underwater camera. In: W. Arntz and M. Gorny (eds), Cruise Report of the Joint Chilean-German-Italian Magellan "Victor Hensen" Campaign in 1994. Ber. Polarforsch., 190: 35 - 41.

Heip, C., M. Vincx and G. Vranken. - 1985 The ecology of marine nematodes. Oceanogr. Mar. Biol. Ann. Rev., 23: 399-489.

Herman, R.L. and H.U. Dahms. - 1992. Meiofauna communities along a depth transect off Halley Bay (Weddell Sea - Antarctica). Polar Biol., 12: 313-320.

Hill, M.O. - 1973. Diversity and evenness: a unifying notation and its consequence. Ecology, 54: 427-432.

Hill, M.O. - 1979. TWINSPAN - a FORTRAN Program for Arranging Multivariate Data in an Ordered two-way Table by Classification of Individuals and Attributes. Cornell University, Ithaca, NY.

Medeiros, C. and B. Kjerfve. - 1988. Tidal characteristics of the Strait of Magellan. Cont. Shelf Res., 8: 947-960.

Michelato, A., E. Accerboni and P. Berger. - 1991. Current meter observations in the eastern and central sectors of the Strait of Magellan. Boll. Oceanol. Teor. Appl.., 9 (2-3): 261-272.

Ott, A. and R. Machan. - 1971. Dynamics of climatic parameters in intertidal sediments. Thalassia Jugoslavica., 7: 219-229.

Ott, J. and F. Schiemer. - 1973. Respiration and anaerobiosis of free living nematodes from marine and limnic sediments. Neth. J. Sea Res., 7: 233-243.

Palmer, M.A. and G. Gust. - 1985. Dispersal of meiofauna in a turbulent tidal creek. J. Mar. Res., 43: 179-210.

Panella, S., A. Michelato, R. Perdicaro, G. Magazzù, F. Decembrini and P. Scarazzato. - 1991. A preliminary contribution to understanding the hydrological characteristics of the Strait of Magellan: Austral spring 1989. Boll. Oceanol. Teor. Appl.., 9 (2-3): 107-126.

Pfannkuche, O. - 1985. The deep-sea meiofauna of the Porcupine seabight and abyssal plain (NE Atlantic): Population structure, distribution, standing stocks. Oceanol. Acta, 8: 343-353.

Pfannkuche, O. and H. Thiel. - 1987. Meiobenthic stocks and benthic activity on the NE-Svalbard Shelf and in the Nansen Basin. Polar Biol., 7: 252-266.

Shirayama, Y. - 1984. The abundance of deep sea meiobenthos in the Western Pacific and the relation to environmental factors. Oceanol. Acta, 7: 113-121.

Snider, L.J., B.R. Burnett and R.R. Hessler. - 1984. The composition and distribution of meiofauna and nanobiota in a central North Pacific deep-sea area. Deep-Sea Res., 31: 1225-1249.

Soetaert, K., C. Heip and M. Vincx. - 1991 The meiobenthos along a Mediterranean deep-sea transect off Calvi (Corsica) and in an adjacent canyon. PSZNI Mar. Ecol., 12: 227-242.

Ter Braak, C.J.F. - 1988. CANOCO, A Fortran Program for Canonical Community Ordination by (Partial) (Detrended) 
(Canonical) Correspondence Analysis, Principal Component Analysis and Redundancy Analysis (vers. 2.1). Agricult. Mat. Group, Ministry Agricult. Fish., Wageningen, The Netherlands. Thiel, H. - 1979. First quantitative data on the deep Red Sea benthos. Mar. Ecol. Prog. Ser., 1: 347-350.

Thiel, H. - 1983. Meiobenthos and nanobenthos of the deep-sea. In: G. T. Rowe (ed.): Deep-Sea Biology, pp. 167-230. Wiley-Interscience, New York.

Thistle, D., J.Y. Yingst and K. Fauchald. - 1985. A deep-sea benthic community exposed to strong near-bottom currents on the Scotian Rise (Western Atlantic). Mar. Geol., 66: 91-112.

Vanhove, S. - 1997. Antarctic sublittoral meiofauna: focus on the ecology of free living marine nematodes. Ph. D. thesis, State Univ. Ghent.

Vanhove, S., H.J. Lee, M. Beghyn, D. Van Gansbeke, S. Brockington and M. Vincx. - 1998. The metazoan meiofauna in its biogeochemical environment: the case of an Antarctic coastal sediment. J. Mar. Biol. Ass. U.K. , 78: 411-434.
Vanhove, S., J. Wittoeck, G. Desmet, B. Van den Berghe, R. L. Herman, R.P.M. Bak, G. Nieuwland, J.H. Vosjan, A. Boldrin, S. Rabitti and M. Vincx. - 1995. Deep-sea meiofauna communities in Antarctica: structural analysis and relation with the environment. Mar. Ecol. Prog. Ser., 127: 65-76.

Vanreusel, A., M. Vincx, D. Van Gansbeke and W. Gijselinck. 1992. Structural analysis of the meiobenthos communities of the shelf break area in two stations of the Gulf of Biscay (N.E. Atlantic). Belg. J. Zool., 122 (2): 185-202.

Vincx, M., B.J. Bett, A. Dinet, T. Ferrero, A.J. Gooday, P.J.D. Lambshead, O. Pfannkuche, T. Soltwedel and A. Vanreusel. 1994. Meiobenthos of the deep northeast Atlantic. Adv. Mar. Biol., 30: 1-88.

Warwick, R.M., J.D. Goss-Custard, R. Kirby, C.L. George, N.D. Pope and A.A. Rowden. - 1991. Static and dynamic environmental factors determining the community structure of estuarine macrobenthos in SW Britain: Why is the Severn estuary different? J. Appl. Ecol., 28: 329-345. 